\title{
Determining the buyer-supplier relationships in international market: evidence of Indonesian products
}

\author{
Ervyna Rizki Febrianny*; Mustika Sufiati Purwanegara
}

\author{
School of Business and Management, Institut Teknologi Bandung, Indonesia \\ *To whom correspondence should be addressed: ervyna_rizki@sbm-itb.ac.id
}

\begin{abstract}
.
This paper examines how trust and commitment impact repurchase intention and relationship performance in international market from overseas buyers to Indonesian suppliers. To achieve this objective, data were collected through a survey using a structured questionnaire to overseas buyers who have been engaging with Indonesian suppliers. A total respondent of 84 were collected. A confirmatory factor analysis was measured in this study to test the reliability and validity of the measurement model. The Partial Least Square technique also was used to test the conceptual framework of this study. The result shows that trust is significantly influenced commitment in the International buyer-supplier relationship. Commitment also significantly influenced repurchase intention and relationship performance of overseas buyers in buying Indonesian products.
\end{abstract}

Keywords: B2B Relationship, Emerging country, Indonesia, International marketing

JEL classification: F14, F23, M31

\section{INTRODUCTION}

Relationship marketing has brought serious both in academic and managerial consideration in the last two decades (Whipple, Lynch, \& Nyaga, 2010). In the international world marketing, the growing globalization, integration of the world economy, and liberalization have been responsible for encouraging an increasing number of firms to engage in international business movements (Czinkota \& Ronkainen, 2007). The very significance of these activities lies in the structure, development, and maintenance of cross-national relationships (Holm, Eriksson, \& Johanson, 1996; Leonidou \& Kaleka, 1998). This happens because shaping strong working relationships can bring benefits for both parties (e.g., cross-selling opportunities, repeat sales, minimization of customer switching, source of innovative ideas) and importers (e.g., cost reduction and rationalization, better purchasing prices, efficiency improvement, access to technical expertise) (Sheth \& Sharma, 1997). However, to get this benefit, it is very important to have trustworthy partners who are willing to work hard and show commitment to the relationship (Evangelista, 1996).

Trust is normaly noted as one of the key elements in prosperous channel relationships (Doney \& Cannon, 1997; Palmatier, Dant, \& Grewal, 2007) and is considered important for cooperation between the channel parties (Morgan \& Hunt, 1994).Trust has been investigated for years in several disciplines and continues to attract the interest of researchers in business-to-business (B2B) marketing (Akrout, 
Diallo, Akrout \& Chandon, 2016). In relationship marketing, trust has been recognized as an essential concept (Lagrosen \& Lagrosen, 2012). Trust is synonymous with integrity and trustworthiness. Trust is also considered as existing when one party has trust in the reliability and integrity of the other exchange partner (Morgan \& Hunt, 1994; Davey \& Powers, 2016).

Commitment defines as a desire to continue a relationship with a partner (Richey \& Myers, 2001). In buyer-supplier contexts, commitment is defined as a desire for continued relationship and an effort to ensure its continuance (Anderson \& Narus, 1984; Morgan \& Hunt, 1994; Wilson, 1995; Valtakoski, 2015) or as a pledge for relational continuity between exchange partners (Dwyer, Schurr, \& Oh, 1987). Commitment has been studied in buyer-seller relationships (Anderson \& Weitz, 1992; Zabkar \& Brencic, 2004), strategic alliances (Cullen, Johnson, \& Sakano, 2000), marketing strategic alliances (Voss, Johnson, Cullen, Sakano, \& Takenouchi, 2006), and cross-border relationships (Styles, Patterson, \& Ahmed, 2008).

It has significantly been demonstrated that a powerful buyer-seller relationship goes to increase repurchase intention (Hewett, Money, \& Sharma, 2002; Frank, Enkawa \& Schvaneveldt, 2015; Agag, 2019) which is generally determined as a buyer's willingness to become involved in future transactions. Previous studies (Wind, 1970; Kleinaltenkamp, Plinke, \& Söllner, 2015) defined that industrial buyers will continue relationships if cost savings are significant that industrial buyers are more appropriate to continue relationships if cost savings are significant and if other departments within the buying companies recommend the suppliers' products. Buyers are likely to be more satisfied when they perceive strong relationships with suppliers and thus more likely to rebuy (Cannon \& Perreault, 1999). Numbers of evidence in the marketing literature stated that strong relationships lead to higher repurchase intention (Hewett, Money \& Sharma, 2006).

Relationship performance can be appraised in many ways. It has been evaluated in terms of cost savings, ability and other aspects of general financial performance that increase from the buyer-seller relationship (Lee, Sirgy, Brown \& Bird, 2004). Consistent with research on business-to-business relationship situations, previous researchs find that trust and commitment bind the importer and exporter to a relationship and help ease task complexity, high uncertainty, and contractual rigidities (Ambler \& Styles, 2000; Zabkar \& Brenic, 2004; Voss, Johnson, Cullen, Sakano, \& Takenouchi, 2006; Berthon, Ewing, \& Napoli, 2008), all of which affect long-term success (Cullen, Johnson \& Sakano, 2000).

\section{HYPOTHESES DEVELOPMENT}

A typical finding that has emerged from previous studies that trust, and commitment are essential for exporter and importer to outcome the positive relationship, including performance relationship quality, and satisfaction (Skarmeas, Katsikeas, \& Schlegelmilch, 2002; Lohtia, Daniel, Yamada \& Gilliland, 2005; Nevins \& Money, 2008; Styles, Patterson, \& Ahmed, 2008). Constant with previous studies regarding business-to-business relationship conditions, those studies discover that trust and commitment bind the importer and exporter to a relationship and help mitigate task complexity, high uncertainty, and contractual rigidities, and all of problems which affect long-term success (Cullen, Johnson \& Sakano, 2000).

Morgan \& Hunt (1994) pointed trust and commitment are the key mediating variables in business relationships. Doney \& Cannon (1997) observed that five separate 
processes to to build trust in a supplier and a salesperson were positively correlated with selection of a supplier. Trust and commitment are fundamental elements for the success of the relationship marketing strategy (Siguaw, Simpson, \& Baker, 1998). Intercompany relations are guided by relational factors such as commitment standards, which are based on trust (Cambra-Fierro \& Polo-Redondo, 2011).

Trust uses as a basis for strengthening the commitment relationship in organizational sciences (Cambra-Fierro \& Polo-Redondo, 2011). Trust determines the desire to depend on an exchange partner in whom one has confidence (Moorman, Zaltman \& Deshpande, 1992). Beliefs in interpersonal trustworthiness (reliability of promises, honesty, helpfulness, and mutual interests in business relationships) serve as indicators of trust in buyer-seller relationships (Jap, 1999). Thus, this study hypothesized:

H1: Trust is positively influenced commitment in the international buyer-supplier relationship.

Buyers will repurchase if there is a high level of trust and commitment (Morgan \& Hunt, 1994), interdependence, and buyer power (Kumar, Scheer \& Steenkamp, 1995). Ganesan (1994) evaluated how buyer dependence, trust, and commitment in a vendor influence long-term sales. Commitment has been pointed out as an important component of close relationships in business-to-business marketing (Chang, Wang, Chih, \& Tsai, 2012; Raineri \& Paillé, 2016; Yousef, 2017). Secure communication, planning, and mutual performance reviews also create greater repurchase intention (Paun, 1997; Money, Hewett \& Sharma, 2002; Hewett, Money \& Sharma, 2006). Moreover, when buyers see strong relationships with suppliers, they tend to be more satisfied (Cannon \& Perreault, 1999) and so that there are more likely to rebuy. An importer's commitment perspective in the internationalization process is as essential for the exporter as its is for importer to build a long-term relationship (Saleh, Ali \& Julian, 2014). Thus, this study hypothesized that:

H2: Commitment is positively influenced repurchase intention in the international buyer-supplier relationship.

A usual finding that has emerged from these studies is that trust and commitment are vital for exporter as well as importer creates positive relationship outcomes, including performance (Skarmeas, Katsikeas \& Schlegelmilch, 2002; Lohtia, Daniel, Yamada \& Gilliland, 2005; Nevins \& Money, 2008; Skarmeas \& Robson, 2008; Styles, Patterson, \& Ahmed, 2008). Many studies have found trust improves partner performance (Cullen, Johnson \& Sakano, 2000; Katsikeas, Skarmeas \& Bello, 2009). Further, the term commitment indicates a desire to continue a relationship with a partner (Richey \& Myers, 2001). Skarmeas, Katsikeas \& Schlegelmilch (2002) figured out that importer's commitment has a positive impact on importer relationship performance. Several studies have suggested the importance of trust and commitment (Anderson \& Weitz, 1992; Zabkar \& Brencic, 2004; Moore, \& Ratneshwar, 2015; Frankel, Mollenkopf, Russo, Coleman \& Dapiran, 2016) in maintaining buyer-seller bond. Trust and dependence of the buyer on seller (an antecedent of commitment) also affect the long-term orientations of both parties (Ganesan, 1994). Commitment positively affect 
the relationship performance between importer and exporter (Lee, Sirgy, Brown \& Bird, 2004). Thus, this study hypothesized that:

H3: Commitment is positively influenced relationship performance in the international buyer-supplier relationship.
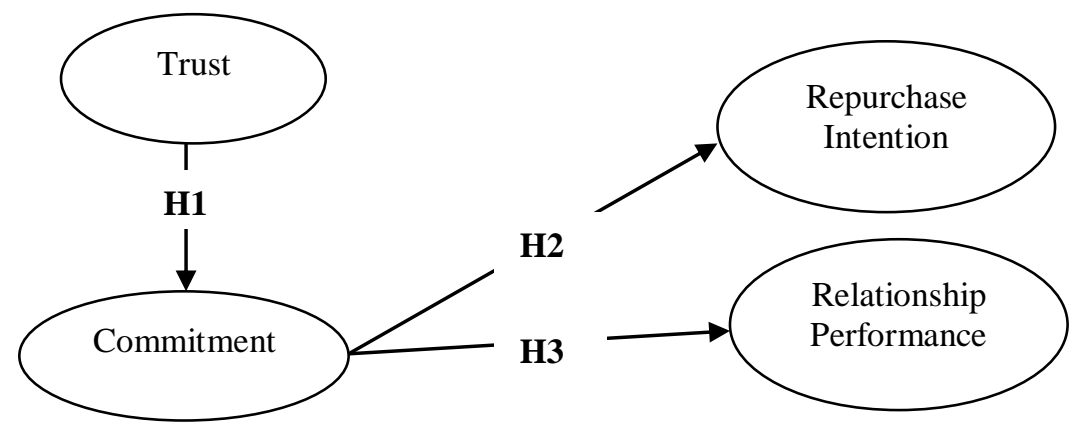

Graph 1. Hypotheses development of the research

\section{METHODS}

\section{The sampling processes}

Data were collected through survey using a structured questionnaire to overseas buyers who have been engaging with Indonesian suppliers. The survey was posted in hard copy and soft copy. The hard copy questionnaire was spread by the International business concentration of Bachelor of Management at SBM-ITB that were doing their exchange program outside the country. The soft copy questionnaire was spread in social media, namely Facebook and emails of overseas buyers. 128 responses were collected. 44 data were rejected because of missing data in the questionnaire. Therefore, the total sample of this research was 84 .

\section{Data analysis}

The Confirmatory Factor Analysis (CFA) was tested in this study. The purpose of our survey is to test the construct that we have collected from the previous study regarding international buyer-supplier relationships. Our conceptual framework was then tested with Smart - Partial Least Square (Smart-PLS). The Smart-PLS procedure is appropriate to test the relationship between each variable in the framework and how well the proposed conceptual framework that contains observed variables and unobserved variables fit the collected data. This study used three-time iterations.

A further criterion in SMART-PLS analysis, the prediction on model quality can be examined with $\mathrm{R}^{2}$. The value of $\mathrm{R}^{2}$ is the squared correlation between actual endogenous variables with predictions (Hair, Hult, Ringle \& Sarstedt, 2016). The value of $\mathrm{R}^{2}$ implies that the combined effect of exogenous variable able to explain some variances of the endogenous variable.

\section{Measurement model}

Confirmatory factor analysis (CFA) was used to test for validity and reliability. For reliability issues, Cronbach's Alpha $(\alpha)$ that need to be examined. Excellent reliability will be achieved once both criterion values can exceed threshold 0.7 (Nunnally \& Bernstein, 1994; Hair, Black, Babin, Anderson, \& Tatham, 2010). The 
validity quality for variables is constructed by using convergent and discriminant validity. Convergent validity, which aims to check if a group measurement of indicator joined the same group correctly. It determines that the output of convergent validity is anticipating the undimensional to appear in a group of measurement indicators by testing the value of Average Variance Explained and factor loading. The value of AVE in a group of variables must be at least 0.5 (Henseler, Ringle \& Sinkovics, 2009). If it is found to be less than 0.5, then the item will be eliminated (Hulland, 1999; Hair, Black, Babin, Anderson \& Tatham, 2010; Memon \& Rahman, 2014). Construct validity defines with two criterions which are Fornell-Larcker criterion and cross loading. For Fornell-Larcker criterion, undimensional does not exist once the correlation value between the latent variable is smaller than the value of the SQRT AVE variable (Fornell \& Larcker, 1981). While for the cross loading undimensional is not found if an indicator does not have a greater loading value on other variables than the variables it belongs to (Chin, 1998; Götz, Liehr-Gobbers \& Krafft, 2010).

\section{Indicators and variables}

The indicators and variables in this study are detailed in the appendix. The indicators of trust we adapted from a paper that is widely used by researchers to measure the buyer-supplier relationship namely, Doney \& Cannon (1997) that explains the promises that keep holding on to suppliers, believe in supplier, being concerned to business succeed, consideration of welfare as well as its own, keep the best interest in mind, and trustworthy. Besides, the indicators of commitment we also adapted from Morgan \& Hunt (1994) that describes business commitment, business importance, maintain business indefinitely, family business look alike, and being cared to the business.

Repurchase intention variable in this research derived from several previous studies (Paun, 1997; Money, Hewett \& Sharma, 2002; Hewett, Money \& Sharma, 2006; Saleh, Ali \& Julian, 2014). It explains the future increasing purchase, future receiving a larger share, and future expansion of suppliers. The variable of relationship performance also derived from previous literature (Skarmeas, Katsikeas \& Schlegelmilch, 2002; Lee, Sirgy, Brown \& Bird, 2004; Lohtia, Daniel, Yamada \& Gilliland, 2005; Nevins \& Money, 2008; Skarmeas \& Robson, 2008; Styles, Patterson \& Ahmed, 2008; Cullen, Johnson \& Sakano, 2000; Katsikeas, Skarmeas \& Bello, 2009) that explains increasing profitability, performing better financially, and cost savings.

\section{RESULTS AND DISCUSSION}

\section{Respondent's profile}

This sub chapter explains the demographic characteristics of our respondents. It includes the nationality of overseas buyers and their export experience in year. Table 1 shows the demographic characteristic of the overall respondents. The respondents of our research are 84 respondents from 29 nations. The majority of the overseas buyers are from the United States which has 12 people. It follows Japan that has 8 people who have been engaging with Indonesian suppliers in the field of export import. The least people who have been cooperating with Indonesian suppliers are from Italy, Norway, Spain, United Kingdom, Afghanistan, Lebanon, Turkey, Yemen, Chile, and Suriname which has 1 person in each country. 
Table 1. Demographic characteristics of respondents

\begin{tabular}{|c|c|c|}
\hline Characteristics & Number & Percentage (\%) \\
\hline \multicolumn{3}{|c|}{ The nationality of overseas buyers } \\
\hline Belgium & 3 & 3.57 \\
\hline Germany & 4 & 4.76 \\
\hline Italy & 1 & 1.19 \\
\hline Netherland & 1 & 1.19 \\
\hline Norway & 1 & 1.19 \\
\hline Spain & 1 & 1.19 \\
\hline UK & 1 & 1.19 \\
\hline Afghanistan & 1 & 1.19 \\
\hline China & 4 & 4.76 \\
\hline India & 4 & 4.76 \\
\hline Japan & 8 & 9.52 \\
\hline Kuwait & 2 & 2.38 \\
\hline Lebanon & 1 & 1.19 \\
\hline Malaysia & 3 & 3.57 \\
\hline Saudi Arabia & 3 & 3.57 \\
\hline Singapore & 3 & 3.57 \\
\hline South Korea & 6 & 7.14 \\
\hline Turkey & 1 & 1.19 \\
\hline Yemen & 1 & 1.19 \\
\hline Egypt & 2 & 2.38 \\
\hline Gambia & 3 & 3.57 \\
\hline Johannesburg & 5 & 5.95 \\
\hline Nigeria & 4 & 4.76 \\
\hline Canada & 4 & 4.76 \\
\hline USA & 12 & 14.28 \\
\hline Brazil & 2 & 2.38 \\
\hline Chille & 1 & 1.19 \\
\hline Suriname & 1 & 1.19 \\
\hline Australia & 2 & 2.38 \\
\hline \multicolumn{3}{|l|}{ Export experience } \\
\hline $1-5$ Years & 40 & 47.60 \\
\hline 6-10 Years & 21 & 25.00 \\
\hline 11-15 Years & 6 & 7.14 \\
\hline 16-20 Years & 6 & 7.14 \\
\hline 21-25 Years & 3 & 3.57 \\
\hline 26-30 Years & 2 & 2.38 \\
\hline 31 Years and over & 6 & 7.14 \\
\hline
\end{tabular}

We can conclude that most overseas buyers have been engaging export-import relations with Indonesia between 0 and 5 years with the value of 48 percent of total respondents. After that, around 25 percent of the total respondents have been cooperating in export-import with Indonesia for approximately 6 to 10 years. Around 7 percent of the total respondents have been collaborating with Indonesia around 11 to 15 years, 16 to 20 Years, and 31 and over. Furthermore, around 4 percent of total respondents have been cooperating with Indonesia for approximately 16 to 20 years. The least are around 26 to 30 years with a value of 2 percent of the total respondents.

\section{Measurement model}

In the third iteration we can see that every indicator has outerloading value of more than 0.7 as well as the Cronbach Alpha $(\alpha)$ in every variable. In addition, the Average Variance Extracted (AVE) value of all variables are over 0.5 which means that the data is completely fine. The discriminant validity can be evaluated by using cross- 
loading of indicator, Fornell \& Larcker criterion and Heterotrait-monotrait (HTMT) ratio of correlation. However, current study selects HTMT critetion to assess the discriminant validity since Henseler, Ringle \& Sinkovics (2009). The result confirmed that the all correlation coefficient of the two different dimensions are smaller than 0,9 except in Trust to Commitment which has the value of $>0.9$ (0.935).

Therefore, we reduce one indicator according to the results of the interview with ITPC as an expert in the field of export-import. The interview states that the C3 indicator which describes a maintain business indefinitely has no effect on the exportimport process between overseas buyers and Indonesian suppliers. Therefore, we remove the C3 indicator and recalculate it. According to Diamantopoulous \& Siguaw (2006), collinearity among construct is declared non-exist if the VIF value is less than 3. The path coefficient $(\beta)$ is representing the relationship between variables on the hypothesis while $t$-value is checked to find the significance. The $(\beta)$ value and the sign of relationship is range from -1 to +1 where according to Hair, Hult, Ringle \& Sarstedt (2016) the value of +1 indicates a stronger positive relationship.

Table 2. Overall CFA for the modified measurement model

\begin{tabular}{|c|c|c|c|c|c|}
\hline $\begin{array}{l}\text { Research } \\
\text { Variables }\end{array}$ & Indicator & Outerloading & $\begin{array}{c}\text { Cronbach's } \\
\text { Alpha }(\alpha)\end{array}$ & AVE & $\mathrm{CR}$ \\
\hline \multirow[t]{2}{*}{ Trust } & Being concerned to business succeeds & 0.906 & & & \\
\hline & Keep the best interest in mind & 0.917 & 0.796 & 0.830 & 0.907 \\
\hline \multirow[t]{4}{*}{ Commitment } & Business commitment & 0.711 & & & \\
\hline & Business importance & 0.878 & & & \\
\hline & Maintaining business indefinitely & 0.864 & 0.815 & 0.638 & 0.875 \\
\hline & Being cared to the business & 0.728 & & & \\
\hline \multirow{3}{*}{$\begin{array}{l}\text { Repurchase } \\
\text { intention }\end{array}$} & Future increasing purchase & 0.820 & & & \\
\hline & Future receiving a larger share & 0.866 & & & \\
\hline & Future expansion of supplies & 0.774 & 0.758 & 0.673 & 0.861 \\
\hline Relationship & Increasing profitability & 0.758 & & & \\
\hline \multirow[t]{2}{*}{ Performance } & Performing better financially & 0.859 & 0.709 & 0.633 & 0.838 \\
\hline & Cost savings & 0.767 & & & \\
\hline
\end{tabular}

After recalculating the discriminant validity test, we finally obtained a value of the trust to commitment correlation coefficient of 0.869 or $<0.9$. This means that the data is completely fine, and it does not have to be improved or replaced.

Table 3. Discriminant validity test (HTMT)

\begin{tabular}{ccccc}
\hline Construct & $\mathrm{T}$ & $\mathrm{C}$ & $\mathrm{RI}$ & $\mathrm{RP}$ \\
\hline $\mathrm{T}$ & & & & \\
$\mathrm{C}$ & 0.869 & & & \\
$\mathrm{RI}$ & 0.597 & 0.666 & & \\
$\mathrm{RP}$ & 0.839 & 0.772 & 0.898 & \\
\hline
\end{tabular}

\section{Structural model}

After the assessment in the measurement conceptual framework is carried out and this shows the results that are in accordance with the standard, it is time to continue the process of data analysis in the structural model. In the structural model assessment, Hair, Hult, Ringle \& Sarstedt (2006) mention that there are some criterions which must be checked. Hence, current study examines collinearity (VIF), path coefficient $(\beta)$, coefficient of determination $\left(\mathrm{R}^{2}\right)$. The score of collinearity and path coefficients are listed in Table 4. 
Table 4. Path coefficient and collinearity for structural model

\begin{tabular}{cccccccc}
\hline Hypothesis & Path & \multicolumn{4}{c}{ Path Coefficient } & \multicolumn{2}{c}{ Collinearity } \\
\cline { 3 - 7 } & & $\beta$ & T-Value & P-Value & Result & VIF & Result \\
\hline H1 & T $\rightarrow$ C & 0.720 & 17.040 & $0.000^{* * *}$ & Supported & 1.000 & No Collinearity \\
H2 & C $\rightarrow$ RI & 0.520 & 5.540 & $0.000^{* * *}$ & Supported & 1.000 & No Collinearity \\
H3 & C $\rightarrow$ RP & 0.600 & 8.560 & $0.000^{* * *}$ & Supported & 1.000 & No Collinearity \\
\hline
\end{tabular}

Significant at: $* \mathrm{p}<0,1 ; * * \mathrm{p}<0,05 ; * * * \mathrm{p}<0,01$

The result shows that coefficient value $(\beta)$ is range from 0.520 until 0.720 using varied two-tailed test significance levels with $\mathrm{p}<0.01, \mathrm{p}<0.05$ and $\mathrm{p}<0.1$. With this, all hypotheses are supported.

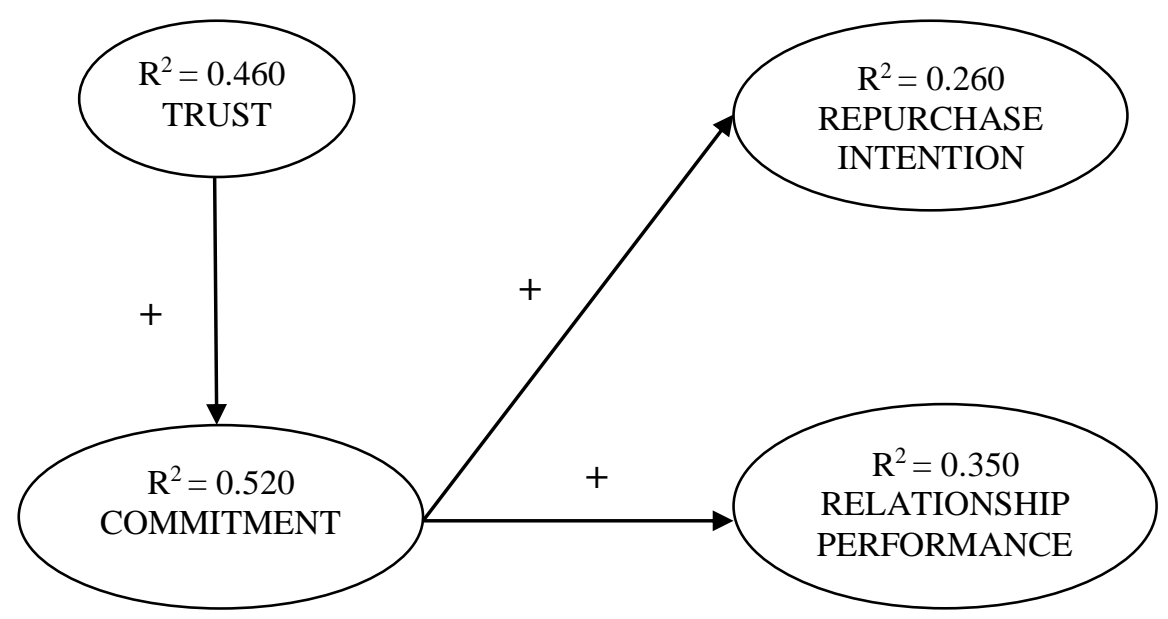

Graph 2. Conceptual framework with adjusted $\mathrm{R}^{2}$

In this model, there are four endogenous variable which are Trust $\left(R^{2}=0.460\right)$, Commitment $\left(\mathrm{R}^{2}=0.520\right)$, Repurchase Intention $\left(\mathrm{R}^{2}=0.260\right)$, and Relationship Performance $\left(\mathrm{R}^{2}=0.350\right)$. This means that Trust, Commitment, Repurchase Intention, and Relationship Performance are categorized into the variable with moderate $\mathrm{R}^{2}$ level $\left(\mathrm{R}^{2}>0.33\right)$. Finally, the result of structural model assessment can be seen in Graph 2 . Our result indicates that trust is significantly influenced commitment in the buyersupplier relationships in International market of Indonesian products. From the results of statistical value, commitment also shows significant results on repurchase intention and relationship performance.

Our result also stated on previous study that trust and commitment are noteworthy drivers of exchange performance (Morgan \& Hunt, 1994). It is also stated that buyers will repurchase if there is a high degree of trust and commitment. Saleh, Ali \& Julian (2014) said that an importer's commitment perspective in the internationalization process is as essential for the exporter as its is for importer to build a long-term relationship. This is propotional to the result of this study. Other previous study that associated with buyer-seller relationship shows that commitment is essential for exporter and importer to create positive relationship outputs, includes performance (Skarmeas, Katsikeas, \& Schlegelmilch, 2002; Lohtia, Daniel, Yamada \& Gilliland, 2005; Nevins \& Money, 2008; Skarmeas \& Robson, 2008; Styles, Patterson, \& Ahmed, 2008). 


\section{CONCLUSIONS AND RECOMMENDATIONS}

\section{Conclusions}

Topics regarding export import in International market has been conducting by many researchers in developing countries, but only a few has been examining the buyersupplier relationships in Indonesia. Therefore, this research was conducted to fill the gap by analyzing the buyer-supplier relationship in International market, as an evidence of Indonesian products.

The results show that trust and commitment are two essential factors that impact export-import of Indonesian products. After trust and commitment have been formed in this export import process, buyers have the intention to repurchase and they believe that by working with Indonesian suppliers, it creates relationship performance between the two parties.

\section{Recommendations}

Respondents are expected to be classified according to the scale of the company, whether the company is in the lower, middle, or upper class because the results might be different. Not only the size but also the relationship age, distribution intensity, supply intensity, and competitive intensity. If the survey is also given to Indonesian suppliers, we could compare the perspective of overseas buyers and Indonesian suppliers, so that the result can be beneficial for both parties who want to collaborate in export-import. It is also expected that further investigation in collecting survey data questionnaire should be in online form rather than in the offline form or the hardcopy in order to anticipate the existence of missing data. Hence, for further research, which would recreate this study in other developing countries, not only is welcome but also is cordially invited. The managerial implications of this study are not restricted only to highly-level firms, namely those who have been cooperating with Indonesian suppliers in ages, but also for firms who have just collaborated with Indonesian suppliers.

This study is not free from limitations, but further research can efficiently address them so that a stronger understanding of International buying decision. It is because if we have more respondents, we will obtain a better result. A second limitation refers to the heterogeneous characteristics of this research respondents which means that respondents come from well-developed countries as well as less-developed countries. Besides, the research respondent's character also comes from various levels such as from the lowest scale companies to the highest scale companies. As published by the interview results, the longer the company cooperates with overseas buyers, the higher the level of the Indonesian companies.

\section{REFERENCES}

Agag, G. (2019). E-commerce ethics and its impact on buyer repurchase intentions andloyalty: an empirical study of small and medium Egyptian businesses. Journal of Business Ethics, 154(2), 389-410.

Akrout, H., Diallo, M.F., Akrout, W. \& Chandon, J.L. (2016). Affective trust in buyerseller relationships: a two-dimensional scale. Journal of Business \& Industrial Marketing, 31(2), 260-273. 
Ambler, T., \& Styles, C. (2000). The future of relational research in international marketing: Constructs and conduits. International Marketing Review, 17(6), 492508.

Anderson, J.C., \& Narus, J.A. (1984). A model of the distributor's perspective of distributor-manufacturer working relationships. Journal of marketing, 48(4), 6274.

Anderson, E., \& Weitz, B. (1992). The use of pledges to build and sustain commitment in distribution channels. Journal of marketing research, 29(1), 18-34.

Ashnai, B., Henneberg, S.C., Naudé, P., \& Francescucci, A. (2016). Inter-personal and inter-organizational trust in business relationships: An attitude-behavior-outcome model. Industrial Marketing Management, 52, 128-139.

Berthon, P., Ewing, M., \& Napoli, J. (2008). Brand management in small to medium sized enterprises. Journal of Small Business Management, 16(1), 27-45.

Cambra-Fierro, J.J., \& Polo-Redondo, Y. (2011). Post-satisfaction factors affecting the long-term orientation of supply relationships. Journal of Business \& Industrial Marketing, 26(6), 395-406.

Cannon, J.P., \& Perreault Jr, W.D. (1999). Buyer-seller relationships in business markets. Journal of marketing research, 36(4), 439-460.

Chang, S.H., Wang, K.Y., Chih, W.H., \& Tsai, W.H. (2012). Building customer commitment in business-to-business markets. Industrial marketing management, 41(6), 940-950.

Cullen, J.B., Johnson, J.L., \& Sakano, T. (2000). Success through commitment and trust: The soft side of strategic alliance management. Journal of World Business, $35(3), 223-240$.

Czinkota, M.R., \& Ronkainen, I.A. (2007). International marketing. South-Western College Publishing.

Davey, K.S., \& Powers, T.L. (2016). Relationship Commitment and Trust in Interorganizational Networks. In Let's Get Engaged! Crossing the Threshold of Marketing's Engagement Era (pp. 463-464). Springer, Cham.

Doney, P.M., \& Cannon, J.P. (1997). An examination of the nature of trust in buyerseller relationships. Journal of Marketing, 61(2), 35-51.

Dwyer, F.R., Schurr, P.H., \& Oh, S. (1987). Developing buyer-seller relationships. Journal of marketing, 51(2), 11-27.

Evangelista, F.U. (1996). Linking business relationships to marketing strategy and export performance: A proposed conceptual framework. Advances of International Marketing, 8, 59-83.

Frank, B., Enkawa, T., \& Schvaneveldt, S.J. (2015). The role of individualism vs. collectivism in the formation of repurchase intent: A cross-industry comparison of the effects of cultural and personal values. Journal of Economic Psychology, 51, 261-278.

Frankel, R., Mollenkopf, D.A., Russo, I., Coleman, B.J., \& Dapiran, G. P. (2016). What do we Really Know About What we Know? The Nature of Relationship Governance in the Reverse Supply Chain. In Looking Forward, Looking Back: Drawing on the Past to Shape the Future of Marketing (pp. 96-99). Springer, Cham. 
Ganesan, S. (1994). Determinants of long-term orientation in buyer-seller relationships. Journal of marketing, 58(2), 1-19.

Glenn Richey, R., \& Myers, M.B. (2001). An investigation of market information use in export channel decisions-antecedents and outcomes. International Journal of Physical Distribution \& Logistics Management, 31(5), 334-353.

Götz, O., Liehr-Gobbers, K., \& Krafft, M. (2010). Evaluation of structural equation model using the partial least squares (PLS) approach. In Handbook of partial least squares (pp. 691-711). Springer, Berlin, Heidelberg.

Hair Jr, J.F., Black, W.C., Babin, B.J., Anderson, R.E., \& Tatham, R.L. (2010). SEM: An introduction. Multivariate data analysis: A global perspective, 629-686.

Hair Jr, J.F., Hult, G.T.M., Ringle, C., \& Sarstedt, M. (2016). A primer on partial least squares structural equation modeling (PLS-SEM). Sage publications.

Henseler, J., Ringle, C.M., \& Sinkovics, R.R. (2009). The use of partial least squares path modeling in international marketing. In New challenges to international marketing (pp. 277-319). Emerald Group Publishing Limited.

Hewett, K., Money, B.R., \& Sharma, S. (2002). An exploration of the moderating role of buyer corporate culture in industrial buyerseller relationships. Journal of the Academy of Marketing Science, 30(3), 229-239.

Hewett, K., Money, R.B., \& Sharma, S. (2006). National culture and industrial buyerseller relationships in the United States and Latin America. Journal of the Academy of Marketing Science, 34(3), 386-402.

Holm, D.B., Eriksson, K., \& Johanson, J. (1996). Business networks and cooperation in international business relationships. Journal of international business studies, 27(5), 1033-1053.

Jap, S.D. (1999). Pie-expansion efforts: Collaboration processes in buyer-supplier relationships. Journal of marketing Research, 36(4), 461-475.

Katsikeas, C.S., Skarmeas, D., \& Bello, D.C. (2009). Developing successful trust-based international exchange relationships. Journal of international business studies, 40(1), 132-155.

Kleinaltenkamp, M., Plinke, W., \& Söllner, A. (2015). Theoretical perspectives of business relationships: explanation and configuration. In Business Relationship Management and Marketing (pp. 27-54). Springer, Berlin, Heidelberg.

Kumar, N., Scheer, L.K., \& Steenkamp, J.B.E. (1995). The effects of perceived interdependence on dealer attitudes. Journal of marketing research, 32(3), 348356.

Lagrosen, S., \& Lagrosen, Y. (2012). Trust and quality management: Perspectives from marketing and organisational learning. Total Quality Management \& Business Excellence, 23(1), 13-26.

Lee, D.J., Sirgy, M.J., Brown, J.R., \& Bird, M.M. (2004). Importers' benevolence toward their foreign export suppliers. Journal of the Academy of Marketing Science, 32(1), 32-48.

Leonidou, L.C., \& Kaleka, A.A. (1998). Behavioral aspects of international buyer-seller relationships: Their association with export involvement. International Marketing Review, 15(5), 373-397. 
Lohtia, R., Daniel C.B, Yamada, T. \& Gilliland, D.I. (2008).The role of commitment in foreign-Japanese relationships: Mediating performance for foreign sellers in Japan. Journal of Business Research. 58(8), 1009-1018.

Money, R.B., Hewett, K., \& Sharma, S. (2002). National culture, buyer-seller relationships, and repurchase intention in industrial markets, In American Marketing Association, Conference Proceedings (Vol. 13, p. 354). American Marketing Association.

Moore, M., \& Ratneshwar, S. (2015). Customer psychological attachment to service firms: the impact of firm-level and situational variables, In Proceedings of the 1999 Academy of Marketing Science (AMS) Annual Conference (pp. 71-74). Springer, Cham

Moorman, C., Zaltman, G., \& Deshpande, R. (1992). Relationships between providers and users of market research: the dynamics of trust within and between organizations. Journal of marketing research, 29(3), 314-328.

Morgan, R.M., \& Hunt, S.D. (1994). The commitment-trust theory of relationship marketing. Journal of Marketing, 58(3), 20-38.

Nevins, J.L., \& Money, R.B. (2008). Performance implications of distributor effectiveness, trust, and culture in import channels of distribution. Industrial Marketing Management, 37(1), 46-58.

Palmatier, R.W., Dant, R.P., Grewal, D., \& Evans, K.R. (2006). Factors influencing the effectiveness of relationship marketing: A meta-analysis. Journal of Marketing, 70(4), 136-153.

Paun, D.A. (1997). A Study of 'Best' Versus 'Average' Buyer-Seller Relationships. Journal of Business Research, 39 (1), 13-21.

Raineri, N., \& Paillé, P. (2016). Linking corporate policy and supervisory support with environmental citizenship behaviors: The role of employee environmental beliefs and commitment. Journal of Business Ethics, 137(1), 129-148.

Saleh, M.A., Ali, M.Y., \& Julian, C.C. (2014). International buyer behaviourcommitment relationship: An investigation of the empirical link in importing. International Business Review, 23(2), 329-342.

Sheth, J.N., \& Sharma, A. (1997). Supplier relationships: Emerging issues and challanges. Industrial Marketing Management, 26, 91-100.

Siguaw, J.A., Simpson, P.M., \& Baker, T.L. (1998). Effects of supplier market orientation on distributor market orientation and the channel relationship: the distributor perspective. Journal of marketing, 62(3), 99-111.

Skarmeas, D., Katsikeas, C.S., \& Schlegelmilch, B.B. (2002). Drivers of commitment and its impact on performance in cross-cultural buyer-seller relationships: The importer's perspective. Journal of International Business Studies, 33(4), 757-783.

Styles, C., Patterson, P.G., \& Ahmed, F. (2008). A relational model of export performance. Journal of international business studies, 39(5), 880-900.

Valtakoski, A. (2015). Initiation of buyer-seller relationships: The impact of intangibility, trust and mitigation strategies. Industrial Marketing Management, 44, 107-118.

Voss, K.E., Johnson, J.L., Cullen, J.B., Sakano, T., \& Takenouchi, H. (2006). Relational exchange in US-Japanese marketing strategic alliances. International Marketing Review, 23(6), 610-635. 
Whipple, J.M., Lynch, D.F., \& Nyaga, G.N. (2010). A buyer's perspective on collaborative versus transactional relationships. Industrial Marketing Management, 39(3), 507-518.

Wilson, D.T. (1995). An integrated model of buyer-seller relationships. Journal of the Academy of Marketing Science, 23(4), 335-45.

Wind, Y. (1970). Industrial source loyalty. Journal of Marketing Research, 7(4), 450457.

Yousef, D. A. (2017). Organizational commitment, job satisfaction and attitudes toward organizational change: A study in the local government. International Journal of Public Administration, 40(1), 77-88.

Zabkar, V., \& Makovec Brencic, M. (2004). Values, trust, and commitment in business to-business relationships: a comparison of two former Yugoslav markets. International Marketing Review, 21(2), 202-215.

\section{APPENDIX : Indicators and variables}

\begin{tabular}{|c|c|c|c|}
\hline Variable & Indicator & Label & Questionnaire \\
\hline \multirow[t]{6}{*}{ Trust } & $\begin{array}{l}\text { Keep promises to } \\
\text { supplier }\end{array}$ & $\mathrm{T} 1$ & $\begin{array}{l}\text { Indonesian supplier keeps promises it } \\
\text { makes to our business }\end{array}$ \\
\hline & Believe in supplier & $\mathrm{T} 2$ & $\begin{array}{l}\text { We believe in the information that } \\
\text { Indonesian supplier provides us }\end{array}$ \\
\hline & $\begin{array}{l}\text { Being concerned to } \\
\text { business }\end{array}$ & $\mathrm{T} 3$ & $\begin{array}{l}\text { Indonesian supplier is genuinely } \\
\text { concerned that our business }\end{array}$ \\
\hline & $\begin{array}{l}\text { Consideration } \\
\text { welfare as well } \\
\text { Its own }\end{array}$ & $\mathrm{T} 4$ & $\begin{array}{l}\text { When making important decisions, } \\
\text { Indonesian supplier considers our welfare } \\
\text { as well as its own }\end{array}$ \\
\hline & $\begin{array}{l}\text { Keep the best interest } \\
\text { in mind }\end{array}$ & T5 & $\begin{array}{l}\text { We trust Indonesian supplier keeps our } \\
\text { best interest in mind }\end{array}$ \\
\hline & Trustworthy & T6 & Indonesian supplier is trustworthy \\
\hline \multirow[t]{5}{*}{ Commitment } & Business commitment & $\mathrm{C} 1$ & $\begin{array}{l}\text { The relationship that my business has with } \\
\text { Indonesian supplier is something we are } \\
\text { very committed to }\end{array}$ \\
\hline & Business importance & $\mathrm{C} 2$ & $\begin{array}{l}\text { The relationship that my business has with } \\
\text { Indonesian supplier is very important to } \\
\text { my business }\end{array}$ \\
\hline & $\begin{array}{l}\text { Maintaining business } \\
\text { indefinitely }\end{array}$ & C3 & $\begin{array}{l}\text { The relationship that my business has with } \\
\text { Indonesian supplier is something my } \\
\text { business intends to maintain indefinitely }\end{array}$ \\
\hline & $\begin{array}{l}\text { Family business look } \\
\text { alike }\end{array}$ & $\mathrm{C} 4$ & $\begin{array}{l}\text { The relationship that my business has with } \\
\text { Indonesian supplier is very much like } \\
\text { being family }\end{array}$ \\
\hline & $\begin{array}{l}\text { Being cared to the } \\
\text { business }\end{array}$ & $\mathrm{C} 5$ & $\begin{array}{l}\text { The relationship that my business has with } \\
\text { Indonesian supplier is something my } \\
\text { business really cares about }\end{array}$ \\
\hline
\end{tabular}




\begin{tabular}{|c|c|c|c|}
\hline Variable & Indicator & Label & Questionnaire \\
\hline \multirow[t]{3}{*}{$\begin{array}{l}\text { Repurchase } \\
\text { Intention }\end{array}$} & $\begin{array}{l}\text { Future increasing } \\
\text { purchase }\end{array}$ & RI1 & $\begin{array}{l}\text { Our firm expects to increase its purchases } \\
\text { from Indonesian suppliers in the near } \\
\text { future }\end{array}$ \\
\hline & $\begin{array}{l}\text { Future receiving a } \\
\text { larger share }\end{array}$ & RI2 & $\begin{array}{l}\text { In the near future, Indonesian suppliers } \\
\text { will receive a larger share of our business }\end{array}$ \\
\hline & $\begin{array}{l}\text { Future expansion of } \\
\text { suppliers }\end{array}$ & RI3 & $\begin{array}{l}\text { Over the next few years, Indonesian } \\
\text { suppliers will be used more than it is now }\end{array}$ \\
\hline \multirow[t]{3}{*}{$\begin{array}{l}\text { Relationship } \\
\text { Performance }\end{array}$} & Increasing profitability & RP1 & $\begin{array}{l}\text { Our firm's profitability has increased } \\
\text { because of Indonesian suppliers }\end{array}$ \\
\hline & $\begin{array}{l}\text { Performing better } \\
\text { financially }\end{array}$ & RP2 & $\begin{array}{l}\text { The relationship with Indonesian suppliers } \\
\text { helped us perform better financially }\end{array}$ \\
\hline & Cost savings & RP3 & $\begin{array}{l}\text { There is significant cost savings resulting } \\
\text { from doing business with Indonesian } \\
\text { suppliers }\end{array}$ \\
\hline
\end{tabular}

